\title{
KEWENANGAN ANKUM TERHADAP WARGA NEGARA YANG DIMOBILISASI DALAM HUKUM DISIPLIN MILITER ${ }^{1}$
}

\author{
Oleh : \\ Allan Hermit Prasetyo ${ }^{2}$
}

\begin{abstract}
The guidance and development of military law are needed and intended to guarantee the respect for human rights, rule of law and justice in the military environment, which among others are manifested through a system of law and order in the law number 25 of 2014 on the law of military discipline. Under the provisions of article 6 paragraph (1) of law number 25 of 2014, then the law of military discipline should be imposed on any person who under the law equated with the military, including the citizens who are mobilized for their expertise in time of war. The enforcement is considered to be too early, given the sentencing of military discipline for offenders who have violated the law of military discipline must be performed by the Authorized adjudge (Ankum), but on the other hand, the law of number 25 of 2014 on the law military discipline does not provide any explicit and complete arrangements or provisions about the Ankum's authority in enforcing discipline against citizen who are mobilized in time of war. Through the method of the normative legal research with an approach to the concept and approach to legislation, it can be concluded that assesment of vagueness of these arrangements is quite essential, considering that the vaqueness of these arrangements may result in legal uncertainty, therefore, it is needed more complete arrangement in order to implement the provisions of the law of military discipline against citizens who mobilized in time of war.
\end{abstract}

Keywords : Authority, The Authorized adjudge, Citizens who are mobilized.

\begin{abstract}
Abstrak
Pembinaan dan pengembangan hukum militer diperlukan dan ditujukan untuk menjamin terciptanya penghormatan terhadap hak asasi manusia, kepastian hukum dan keadilan di lingkungan militer, yang diantaranya diwujudkan melalui suatu sistem dan tatanan hukum dalam Undang-Undang Nomor 25 Tahun 2014 tentang Hukum Disiplin Militer. Berdasarkan ketentuan Pasal 6 ayat (1) Undang-Undang Nomor 25 Tahun 2014, maka Hukum Disiplin Militer juga diberlakukan kepada setiap orang yang berdasarkan undang-undang dipersamakan dengan militer, diantaranya adalah warga negara yang dimobilisasi karena keahliannya pada waktu perang. Pemberlakuan ini dianggap terlampau dini, mengingat penjatuhan hukuman disiplin militer bagi pelaku yang melakukan pelanggaran hukum disiplin militer harus dilakukan oleh seorang Atasan Yang Berhak Menghukum

\footnotetext{
Artikel ini merupakan karya ilmiah mahasiswa pada Program Studi Magister (S2) Ilmu Hukum Ariawan, SH.,MH dan Dr. Ida Bagus Surya Darmajaya, SH.,MH selaku Pembimbing. Denpasar Bali, email: allanprasetyo98@gmail.com
} Program Pascasarjana Univesitas Udayana serta mengucapkan terimakasih kepada Dr. I Gusti Ketut

2 Mahasiswa Program Studi Magister (S2) Ilmu Hukum Program Pascasarjana Univesitas Udayana,
\end{abstract}


(Ankum), namun di sisi lain, Undang-Undang Nomor 25 Tahun 2014 tentang Hukum Disiplin Militer tidak memberikan pengaturan secara tegas dan lengkap tentang kewenangan Ankum dalam menegakkan hukum disiplin terhadap warga negara yang dimobilisasi pada waktu perang. Melalui penelitian hukum normatif dengan pendekatan konsep hukum dan pendekatan perundangan-undangan, maka dapat disimpulkan bahwa pembahasan tentang kekaburan pengaturan ini merupakan hal yang cukup penting, mengingat kekaburan tersebut dapat menimbulkan ketidakpastian hukum, dan oleh karenanya diperlukan pengaturan lanjutan yang lebih lengkap dalam upaya menerapkan ketentuan hukum disiplin militer terhadap warga negara yang dimobilisasi pada waktu perang.

\section{Kata kunci : Kewenangan, Atasan Yang Berhak Menghukum, Warga negara} yang dimobilisasi.

\section{PENDAHULUAN}

Perkembangan hukum, hak asasi manusia, sosial budaya dan tehnologi yang bergerak demikian cepat telah mempengaruhi dan memberikan perubahan-perubahan pada sikap dan pola pikir Tentara Nasional Indonesia (selanjutnya disebut TNI) yang selanjutnya tertuang di dalam reformasi birokrasi TNI. Dalam upaya responsif menyikapi perkembangan sosial tersebut, maka pengembangan dan pembinaan hukum militer dalam organisasi TNI ditujukan pula untuk mendukung terjaminnyapenghormatan terhadap hak asasi manusia, kepastian hukum dan keadilan di lingkungan militer. Indikasi profesionalitas TNI dalam pembinaan hukum militer diantaranya ditunjukkan dengan adanya kehendak dan kepatuhan untuk mentaati seluruh ketentuan hukum yang berlaku, baik yang berlaku secara khusus di lingkungan internal TNI maupun ketentuan hukum yang berlaku pada umumnya. Dalam memelihara disiplin internal baik personel dan satuan, dalam lingkungan militer dikenal adanya seorang Atasan yang Berhak Menghukum (selanjutnya disebut Ankum) yang memiliki kewenangan hukum berdasarkan undang-undang untuk memelihara tegaknya hukum disiplin militer di lingkungan satuannya. Ankum memiliki peran yang sangat penting dalam memelihara, menegakkan hukum dan disiplin satuan agar tugas pokok TNI dapat tercapai, dengan demikian maka keberadaan seorang Komandan memiliki fungsi hukum untuk menjaga disiplin internal para anggota militer di bawah komandonya. Dalam sudut pandang kemiliteran, bentuk pelanggaran hukum dalam kategori ringan adalah pelanggaran terhadap hukum disiplin, yang dapat diberi pemaknaan secara singkat sebagai perbuatan yang "tidak patut" dilakukan oleh seorang militer. Oleh karenanya, di kembangkanlah suatu sistem dan tatanan hukum yang lebih spesifik dan terinci agar segala sesuatu yang terkait dengan bentuk 
pelanggaran hukum sekecil apapun dapat diselesaikan berdasarkan mekanisme penegakan hukum disiplin yang tertuang dalam Undang-Undang No 25 Tahun 2014 tentang Hukum Disiplin Militer (selanjutnya disebut UUHDM-2014). Natsri Anshari mengutip pendapat David A. Schlueter yang menyatakan bahwa militer juga memiliki dan mengembangkan hukum dan tradisi sendiri selama perkembangan sejarahnya yang panjang. Perbedaan antara masyarakat sipil dan militer diakibatkan dari fakta bahwa bisnis utama dari Angkatan Bersenjata adalah bertempur dan siap berperang jika terjadi ancaman yang membahayakan kedaulatan negara. ${ }^{3}$

Selanjutnya

berdasarkan

ketentuan Pasal 6 ayat (1) UUHDM2014 dinyatakan bahwa Hukum Disiplin Militer diberlakukan kepada:

a. Militer; dan

b. Setiap orang yang berdasarkan undang-undang dipersamakan dengan Militer.

Dalam penjelasan Pasal 6 ayat (1) huruf b UUHDM-2014 dinyatakan bahwa yang dimaksud dengan "Setiap orang yang berdasarkan undangundang dipersamakan dengan Militer" antara lain adalah warga negara yang dimobilisasi karena keahliannya pada waktu perang. Pemberlakuan Hukum Disiplin Militer untuk warga negara yang dimobilisasi ini dianggap

Natsri Anshari, 2014, Perubahan Hukum Disiplin Militer : Disiplin Versus Keadilan,Jurnal Hukum Militer: Vol.2 No. 1., STHM, Jakarta, hlm. 52. terlampau dini, mengingat penjatuhan hukuman disiplin militer bagi pelaku yang melakukan pelanggaran hukum disiplin militer harus dilakukan oleh seorang Ankum. Di sisi lain, Undang-Undang Nomor 25 Tahun 2014 tentang Hukum Disiplin Militer tidak memberikan pengaturan secara tegas dan jelas tentang kewenangan Ankum dalam menegakkan hukum disiplin terhadap warga negara yang dimobilisasi pada waktu perang. Keadaan ini menimbulkan suatu kekaburan dan ketidakpastian hukum dalam upaya menerapkan ketentuan hukum disiplin militer terhadap warga negara yang dimobilisasi pada waktu perang. Berdasarkan uraian latar belakang di atas, maka dalam penelitian ini akan dilakukan pembahasan mengenai kewenangan Ankum dalam menegakkan Hukum Disiplin Militer terhadap Militer dan kewenangan Ankum terhadap warga negara yang dimobilisasi berdasarkan Hukum Disiplin Militer.

Penelitian yang juga mengangkat isu tentang militer yang digunakan sebagai orisinalitas dalam penulisan ini antara lain adalah artikel hukum yang ditulis oleh Sudiro dan Supriyatna. Artikel hukum yang ditulis oleh Sudiro berjudul "Sanksi Hukum Disiplin Militer Dalam Penerapan Dan Konsep Rancangan Undang-Undang Hukum Disiplin Militer"4, dalam artikel $4 \quad$ Sudiro, 2014, Sanksi Hukum Disiplin Militer Dalam Penerapan Dan Konsep Rancangan Undang-Undang Hukum Disiplin Militer, Jurnal Hukum Militer, Vol.2 No. 1., STHM, Jakarta, hlm. 36. 
tersebut Sudiro membahas tentang sanksi hukum disiplin militer dan penerapannya bagi prajurit TNI dan konsep rancangan Hukum Disiplin Militer. Adapun artikel yang ditulis oleh Supriyatna berjudul "Pentingnya Hukum Disiplin Militer Ditinjau Dari Aspek Pembinaan Prajurit TNI"5. Dalam artikel ini Supriyatna menitikberatkan pembahasan mengenai pentingnya hukum disiplin militer dari aspek pembinaan personel.

Dari kedua artikel hukum tersebut, maka dapat diketahui bahwa penulisan ini memiliki perbedaan dari penulisanpenulisan sebelumnya, karena dalam penulisan ini lebih menitikberatkan pembahasan tentang kewenangan Ankum terhadap warga negara yang dimobilisasi berdasarkan Hukum Disiplin Militer.

Tujuan dari penulisan ini adalah untuk memberikan kontribusi ilmu pengetahuan dibidang hukum militer, khususnya tentang pentingnya pengaturan kewenangan Ankum secara lengkap terhadap warga negara yang dimobilisasi berdasarkan ketentuan Hukum Disiplin Militer.

\section{METODE PENELITIAN}

Metode penelitian yang digunakan dalam penulisan ini adalah penelitian hukum normatif. Menurut Mukti Fajar ND dan Yulianto Ahmad, yang dimaksud penelitian hukum

Supriyatna, 2014, Pentingnya Hukum Disiplin Militer Ditinjau Dari Aspek Pembinaan Prajurit TNI, Jurnal Hukum Militer, Vol.2 No. 1., STHM, Jakarta, hlm. 1. normatif adalah penelitian hukum yang meletakkan hukum sebagai sistem norma. Sistem norma yang dimaksud adalah mengenai asas-asas, norma, kaidah dari peraturan perundangundangan, putusan pengadilan, perjanjian serta doktrin (ajaran). ${ }^{6}$ Penelitian hukum normatif ini berawal dari masalah adanya kekaburan norma hukum dalam Undang-undang Nomor 25 Tahun 2014 tentang Hukum Disiplin Militer, khususnya ketentuan yang mengatur tentang kewenangan Ankum dalam menegakkan hukum disiplin terhadap warga negara yang dimobilisasi.

Dalam penelitian ini, jenis pendekatanyangdigunakandiantaranya adalah pendekatan analisis dan konsep hukum (analitical and conseptual approach) dan pendekatan perundangundangan (statute approach). Pendekatan analisis dan konsep hukum dilakukan dengan menganalisa konsep dan teori hukum yang berhubungan dengan penelitian hukum tentang kewenangan Ankum dalam menegakkan Hukum Disiplin Militer, sedangkan pendekatan perundangundangan (statute approach) dilakukan dengan menganalisa Undang-Undang Nomor 25 Tahun 2014 tentang Hukum Disiplin Militer dan peraturan lain yang terkait dengan kewenangan Ankum dalam menegakkan Hukum Disiplin Militer.

\footnotetext{
Mukti Fajar ND dan Yulianto Achmad, 2010, Dualisme Penelitian Hukum Normatif dan Hukum Empiris, Pustaka Pelajar, Yogyakarta,
} hlm. 34 . 
III. HASIL DAN PEMBAHASAN

3.1. Kewenangan Ankum Dalam Hukum Disiplin Militer.

Hukum Disiplin Militer

merupakan serangkaian peraturan dan norma untuk mengatur, membina, menegakkan disiplin, dan tata kehidupan yang berlaku bagi Militer. Penyelenggaraan Hukum Disiplin Militer ditujukan untuk mewujudkan pembinaan organisasi, pembinaan personel, pembinaan dan peningkatan disiplin militer, serta penegakan Hukum Disiplin Militer dengan memperhatikan kemanfaatan dan keadilan.

Pada dasarnya disiplin adalah sesuatu yang diperlukan untuk mempertahankan keteraturan dan ketertiban prajurit dalam hubungan perorangan maupun hubungan satuan untuk melaksanakan setiap tugas kedinasan dalam suatu komando. Disiplin diawali dari diri setiap Militer guna menciptakan stabilitas sikap dan perilaku pada perubahan situasi yang bagaimanapun juga, serta menghindarkan seorang Militer dari perilaku yang bersifat keji dan tidak bermoral. Pemeliharaan disiplin diri merupakan tanggung jawab utama dari seorang Militer yang diperlukan untuk meyakinkan terjaganya kesiapan dan kekuatan militer. Kemenangan dan keunggulan dalam suatu pertempuran tidak hanya ditentukan oleh alat utama sistem persenjataan dan teknologi komputerisasi yang handal, namun lebih daripada itu, bahwa suatu kemenangan juga ditentukan oleh kesiapan bertempur yang diikuti dengan tingkat kedisiplinan yang tinggi.

Memahami bahwa setiap militer dilatih dan ditempa dalam situasi dan kondisiyang tidakmengenalmenyerah, kekuatan dan kekerasan, maka posisi tersebut menempatkan setiap Militer berada dalam posisi yang cukup rentan terhadap terjadinya suatu pelanggaran hukum, khususnya pelanggaran hukum disiplin. Oleh karenanya, di kembangkanlah suatu sistem dan tatanan hukum yang lebih spesifik agar segala sesuatu yang terkait dengan timbulnya pelanggaran hukum sekecil apapun dapat diselesaikan berdasarkan suatu mekanisme penegakan hukum disiplin yang berlaku di lingkungan militer.

Berdasarkan ketentuan Pasal 8 UUHDM-2014, pengaturan jenis-jenis pelanggaran Hukum Disiplin Militer meliputi hal-hal sebagai berikut :

a. Segala perbuatan yang bertentangan dengan perintah kedinasan, peraturan kedinasan, atau perbuatan yang tidak sesuai dengan Tata Tertib Militer. (lalai melakukan penghormatan kepada atasan, mendatangi tempat-tempat terlarang/ prostitusi, berambut gondrong dan lain sebagainya); dan

b. Perbuatan yang melanggar peraturan perundang-undangan pidana yang sedemikian ringan sifatnya. Yang dimaksud dengan 
"perbuatan yang melanggar perundang-undangan pidana yang sedemikian ringan sifatnya" meliputi:

1) Segala bentuk tindak pidana yang digolongkan dalam peraturan perundangundangan terkait dengan ancaman pidana penjara paling lama 3 (tiga) bulan atau kurungan paling lama 6 (enam) bulan;

2) Perkara sederhana dan mudah pembuktiannya;

3) Tindak pidana yang terjadi tidak mengakibatkan terganggunya kepentingan militer dan/atau kepentingan umum; dan

4) Tindak pidana karena ketidakhadiran tanpa izin dalam waktu damai paling lama 4 (empat) hari.

Berkaitan dengan jenis pelanggaran disiplin tersebut, selanjutnya dapat diketahui adanya Hukuman Disiplin Militer yang dapat dijatuhkan kepada Tersangka pelanggar hukum disiplin adalah sebagai berikut :

a. Teguran;

b. Penahanan disiplin ringan paling lama 14 (empat belas) hari; atau

c. Penahanan disiplin berat paling lama 21 (dua puluh satu) hari.

Perbedaan antara penahanan disiplin ringan dan berat terletak pada mekanisme pelaksanaan hukuman yang dijalankan. Dalam pelaksanaan penahanan disiplin ringan, Terhukum dapat menerima tamu dan dapat dipekerjakan di lingkungan satuannya pada saat berlangsungnya jam kerja, sedangkan dalam hal pelaksanaan penahanan berat, Terhukum tidak dapat menerima tamu, tidak dapat dipekerjakan, dan menjalani penahanan tersebut pada tempat yang tertutup.

Dalam menegakkan Hukum disiplin Militer atas terjadinya suatu pelanggaran hukum disiplin, maka UUHDM-2014 memberikan kewenangan kepada Komandan Satuan untuk berkedudukan sebagai Ankum yang bertujuan memelihara dan menegakkan hukum disiplin terhadap satuan yang berada di bawah wewenang komandonya.

Menurut Ateng Syafrudin sebagaimana dikutip oleh Salim HS dan ES Nurbani, kewenangan adalah apa yang disebut dengan kekuasaan formal, kekuasaan yang berasal dari kekuasaan yang diberikan oleh undangundang. ${ }^{7}$ Sedangkan pengertian kewenangan atau authority dalam Black's Law Dictionary adalah :

"Right to exercise powers; to implement and enforce laws; to exact obedience; to command; to judge. Control over; jurisdiction. Often synonymous with power"s

Salim HS dan ES Nurbani, 2014, Penerapan Teori Hukum Pada Penelitian Tesis Dan Desertasi, PT RajaGrafindo Persada, Jakarta, hlm. 184.

Henry Campbell Black, 1978, Black's Law Dictionary, West Publishing Co, USA, hlm. 121. 
Berdasarkan ketentuan Pasal

20 dan Pasal 21 UUHDM-2014 dinyatakan bahwa Ankum berdasarkan kewenangannya antara lain terdiri atas:

1. Ankum berwenang penuh, adalah Ankum yang mempunyai wewenang untuk menjatuhkan semua jenis Hukuman Disiplin Militer kepada Militer yang berada di bawah wewenang komandonya.

2. Ankum berwenang terbatas, adalah Ankum yang mempunyai wewenang untuk menjatuhkan semua jenis Hukuman Disiplin Militer kepada Militer yang berada di bawah wewenang komandonya, kecuali penahanan disiplin berat terhadap perwira.

3. Ankum berwenang sangat terbatas, adalah Ankum yang mempunyai wewenang untuk menjatuhkan Hukuman Disiplin Militer teguran dan penahanan ringan kepada bintara dan tamtama yang berada di bawah wewenang komandonya.

Selanjutnya berdasarkan

ketentuan Pasal 22 dan Pasal 23 UUHDM-2014, maka kewenangan Ankum berdasarkan jenjangnya antara lain adalah sebagai berikut:

1. Ankum, berwenang untuk:

a. Melakukan atau memerintahkan untuk melakukan pemeriksaan terhadap Militer yang berada di bawah wewenang komandonya; b. Menjatuhkan Hukuman

Disiplin Militer terhadap Militer yang berada di bawah wewenang komandonya; dan

c. Menunda pelaksanaan Hukuman Disiplin Militer yang telah dijatuhkan.

2. Ankum Atasan, berwenang untuk:

a. Menunda pelaksanaan Hukuman Disiplin Militer;

b. Memeriksa dan memutuskan pengajuan keberatan; dan

c. Mengawasi dan mengendalikan Ankum di bawahnya.

3. Ankum dari Ankum Atasan, berwenang untuk:

a. Menunda pelaksanaan Hukuman Disiplin Militer;

b. Memeriksa dan memutuskan pengajuan keberatan tingkat akhir; dan

c. Mengawasi dan mengendalikan Ankum di bawahnya.

4. Ankum Tertinggi, berwenang untuk:

a. Menunda pelaksanaan Hukuman Disiplin Militer;

b. Memeriksa dan memutuskan pengajuan keberatan tingkat akhir dan bersifat final; danwww.hukumonline. com

c. Mengawasi dan mengendalikan Ankum di bawahnya. 
Berdasarkan Undang-Undang Nomor31 Tahun 1997 tentangPeradilan Militer,Ankumdiartikan sebagaiatasan langsung yang mempunyai wewenang untuk menjatuhkan hukuman disiplin menurut ketentuan perundangundangan yang berlaku dan berwenang melakukan penyidikan. Kewenangan yang dimiliki oleh seorang Ankum menurut UU No 31 Tahun 1997 yaitu: (i) melakukan penyelidikan terhadap prajurit yang ada di bawah wewenang komandonya; (ii) menerima laporan pelaksanaan penyidikan dari penyidik; (iii) menerima berkas perkara hasil penyidikan; dan (iv) melakukan penahanan terhadap tersangka militer yang ada di bawah komandonya.

Berdasarkan kewenangan yang diberikankepadaAnkumtersebut,maka Ankum memiliki peran yang sangat penting dan dinamis dalam memelihara dan menegakkan hukum disiplin agar tugas pokok satuan dapat tercapai dengan baik. Seorang Ankum harus mampu bertindak secara cepat, cermat dan tegas dalam memimpin satuannya, bukan saja terhadap kemampuan untuk memimpin suatu tugas-tugas kemiliteran dalam pertempuran, tetapi juga kemampuan untuk menjalankan wewenang yang dipercayakan kepadanya secara sederhana, adil, obyektif dan tidak menyalahgunakan wewenang yang dimilikinya. Ankum harus dapat memimpin bawahannya dengan adil dan bijaksana, memiliki kemampuan bertindak sebagai bapak terhadap anak ataupun sebagai guru terhadap muridnya, serta memelihara tegaknya disiplin kemiliteran dan melakukan penindakan hukum secara tegas kepada Militer yang melakukan pelanggaran hukum. Terpelihara dan tegaknya hukum disiplin merupakan salah satu faktor untuk mewujudkan kesiapan personel dan kesiapan operasional satuan guna mendukung keberhasilan pelaksanaan tugas pokok satuan TNI sebagai alat pertahanan negara Republik Indonesia.

\subsection{Kewenangan}

Ankum

Terhadap Warga Negara Yang di Mobilisasi.

Berdasarkan ketentuan Pasal 6 ayat (1) UUHDM-2014, secara limitatif dinyatakan bahwa Hukum Disiplin Militer diberlakukan kepada:

a. Militer; dan

b. Setiap orang yang berdasarkan undang-undang dipersamakan dengan Militer.

Dalam penjelasan Pasal 6 ayat (1) huruf b UUHDM-2014 selanjutnya dapat diketahui bahwa yang dimaksud dengan "Setiap orang yang berdasarkan undang-undang dipersamakan dengan Militer" antara lain adalah warga negara yang dimobilisasi karena keahliannya pada waktu perang. Dengan demikian maka berdasarkan UUHDM-2014, warga negara yang dimobilisasi karena keahliannya pada waktu perang tunduk pada ketentuan hukum yang terdapat dalam Hukum Disiplin Militer. 
Kepentingan mobilisasi dalam suatu negara dimaksudkan sebagai upaya nyata untuk mempertahankan keutuhan negara yang berkaitan dengan penanggulangan negara dalam suatu keadaan bahaya sebagai akibat ancaman dan gangguan baik yang datang dari luar negeri maupun dari dalam negeri yang tidak dapat diatasi oleh Tentara Nasional Indonesia termasuk cadangannya. Oleh karena itu diperlukan tindakan mobilisasi sumber daya nasional beserta seluruh sarana dan prasarana nasional yang telah dipersiapkan sejak dini sebagai komponen yang mendukung kekuatan pertahanan keamanan negara untuk menjamin kelangsungan hidup Negara Kesatuan Republik Indonesia berdasarkan peraturan perundangundangan yang berlaku.

Mencermati ketentuan Pasal 1 Undang-Undang Nomor27Tahun 1997 tentang Mobilisasi Dan Demobilisasi (selanjutnya disebut UUMDD-1997), maka Mobilisasi diartikan sebagai tindakan pengerahan dan penggunaan secara serentak sumber daya nasional serta sarana dan prasarana nasional yang telah dibina dan dipersiapkan sebagaikomponenkekuatanpertahanan keamanan negara untuk digunakan secara tepat, terpadu, dan terarah bagi penanggulangan setiap ancaman, baik dari luar negeri maupun dari dalam negeri. Sedangkan yang dimaksud dengan pengertian Demobilisasi adalah tindakan penghentian pengerahan dan penghentian penggunaan sumber daya nasional serta sarana dan prasarana nasional yang berlaku untuk seluruh wilayah negara yang diselenggarakan secara bertahap guna memulihkan fungsi dan tugas setiap unsur seperti sebelum berlakunya mobilisasi.

Pemberlakuan Hukum Disiplin Militer kepada warga negara yang dimobilisasi karena keahliannya pada waktu perang telah menimbulkan beberapa kerancuan dalam pelaksanaannya.Halinididasarkanpada realita bahwa meskipun keberadaan warga negara yang dimobilisasi telah dipersamakan dengan militer, namun faktanya warga negara tersebut tidak pernah berada dalam kehidupan militer atau bahkan budaya dalam lingkungan militer. Persamaan ini juga dapat dianggap telah menimbulkan suatu pemaksaaan terhadap warga negara yang dimobilisasi untuk tunduk dan harus memahami seluruh tatanan peraturan yang berlaku dalam kehidupan militer dalam waktu yang relatif singkat manakala negara berada dalam keadaan bahaya.

Proses merubah suatu kebiasaan dan budaya bukan merupakan hal yang mudah, dan apabila hal yang demikian dipaksakan hanya untuk memenuhi tuntutan undang-undang, maka akan terdapat kekacauan dalam penerapannya, menimbulkan keresahan dan rasa ketidakadilan, karena sesungguhnya warga negara tersebut pada dasarnya tidak hidup dalam lingkungan militer dan bahkan tidak memahami budaya disiplin 
militer secara sempurna, tetapi harus berhadapan dan beradaptasi dengan hukum militer yang tidak pernah dimengerti sebelumnya. Dalam pada itu, maka adagium "bahwa setiap orang dianggap mengetahui hukum" menjadi tidak relevan dengan persoalan kedisiplinan yang dipaksakan keberlakuannya pada warga negara yang dimobilisasi pada saat negara berada dalam suatu keadaan bahaya.

Selain itu, UUHDM-2014 juga tidak memberikan pengaturan yang jelas tentang perbedaan perlakuan terhadap warga yang dimobilisasi untuk melakukan perlawanan rakyat bersenjata dan perlawanan rakyat tidak bersenjata. Dengan demikian maka UUHDM-2014 menganggap bahwa seluruh warga yang dimobilisasi tunduk kepada Hukum Disiplin Militer. Pemberlakuan ini bertentangan dengan UUMDD-1997 yang secara jelas dan tegas mengatur bahwa hanya terhadap warga yang dimobilisasi dalam suatu tugas untuk melakukan perlawanan rakyat bersenjata yang ditundukkan kepada Hukum Militer, sedangkan terhadap warga negara yang dimobilisasi untuk melakukan tugas perlawanan rakyat tidak bersenjata tidak tunduk pada Hukum Militer. Sebagaimana diketahui, bahwa Hukum Disiplin Militer merupakan bagian kecil dari keberadaan Hukum Militer di Indonesia.

Bahwaataskerancuan-kerancuan tersebut, selanjutnya dapat dipahami pula, bahwa UUHDM-2014 juga tidak memberikan pengaturan yang jelas dan tegas tentang kewenangan Ankum untuk menjatuhkan Hukuman Disiplin Militer terhadap warga negara yang dimobilisasi. Kewenangan Ankum yang disebutkan dalam UUHDM-2014 adalah kewenangan Ankum untuk menjatuhkan Hukuman Disiplin Militer secara terbatas kepada anggota Militer, dan tidak secara tegas mengatur kewenangan Ankum untuk menjatuhkan Hukuman Disiplin Militer terhadap warga negara yang dimobilisasi. Kekaburan norma ini akan menimbulkan kekacauan dan ketidakpastian hukum dalam implementasinya, mengingat UUHDM-2014 tidak memberikan pengaturan yang bersifat limitatif tentang keberadaan dan kedudukan Ankum terhadap warga negara yang dimobilisasi, sedangkan di sisi yang sama, hukum dituntut untuk memberikan suatu keadilan, kepastian hukum dan kemanfaatan bagi seluruh masyarakat.

Sudikno

Mertokusumo menyatakan bahwa kepastian hukum merupakan salah satu syarat yang harus dipenuhi dalam penegakan hukum. Kepastian hukum merupakan perlindungan yustisiabel terhadap tindakan sewenang-wenang, yang berarti bahwa seseorang akan dapat memperoleh sesuatu yang diharapkan dalam keadaan tertentu. ${ }^{9}$

\footnotetext{
Sudikno Mertokusumo, 2007, Mengenal Hukum, Sebuah Pengantar, Liberty, Yogyakarta, hlm.145.
} 
Menurut Van Kan, kepastian hukum adalah perangkat hukum suatu negara yang mampu menjamin hak dan kewajiban setiap warga negara. Kepastian hukum tersebut dibedakan dalam dua macam yaitu: 1) kepastian oleh karena hukum, yaitu hukum menjamin kepastian antara pihak yang satu terhadap pihak yang lainnya, artinya adanya konsistensi penerapan hukum kepada semua orang tanpa pandang bulu, dan, 2) kepastian dalam atau dari hukum, artinya kepastian hukum tercapai jika hukum itu sebanyak-banyaknya undang-undang, tidak ada ketentuan yang bertentangan (undang-undang berdasarkan sistem logis dan pasti), dibuat berdasarkan kenyataan hukum (rechtswerkelijkheid) dan di dalamnya tidak ada istilah yang dapat ditafsirkan secara berlain-lainan (tertutup). ${ }^{10}$

Namun demikian, dalam mengidentifikasi peraturan-peraturan hukum nasional yang berlaku saat ini, tidak jarang ditemukan adanya suatu keadaan aturan hukum; yaitu kekosongan hukum (leemten in het recht), konflik antar norma hukum (antinomi hukum) dan norma yang kabur (vage normen) atau norma yang tidak jelas. ${ }^{11}$

Bahwa adapun kajian tentang adanya kekaburan norma hukum dalam

10 E. Fernando M. Manullang, 2007, Menggapai Hukum Berkeadilan Tinjauan Hukum Kodrat dan Antinomi Nilai, PT. Kompas Media Nusantara, Jakarta, hlm. 92.

11 Ahmad Rifai, 2011, Penemuan Hukum Oleh Hakim Dalam Perspektif Hukum Progresif, Sinar Grafika, Jakarta, hlm.89.
UUHDM-2014, maka diperlukan adanya penafsiran/interpretasi hukum, khususnya Interpretasi Sistematis. Metode ini dilakukan dengan memandang bahwa tak satupun dari peraturan perundang-undangan dapat ditafsirkan seakan-akan berdiri sendiri, tetapi harus dipahami dalam kaitannya dengan jenis peraturan lainnya, atau dengan kata lain bahwa metode ini melihat hukum sebagai satu kesatuan yang utuh, tidak merupakan bagian yang berdiri sendiri tetapi merupakan bagian dari satu sistem. ${ }^{12}$

Sejalan dengan hal ini, Kelsen menjelaskan bahwa hukum adalah tata aturan (order) sebagai suatu sistem aturan-aturan (rules) tentang perilaku manusia. Dengan demikian hukum tidak menunjuk pada satu aturan tunggal (rule), tetapi seperangkat aturan (rules) yang memiliki suatu kesatuan sehingga dapat dipahami sebagai suatu sistem. Konsekuensinya, adalah tidak mungkin memahami hukum jika hanya memperhatikan satu aturan saja. ${ }^{13}$

Berkaitan dengan Interpretasi Sistematis, maka peraturan lain yang dapat digunakan untuk menafsirkan kewenangan Ankum terdapat pada ketentuan Pasal 10 ayat (2) UUMDD1997 yang menyatakan bahwa pendidikan dan pelatihan, penetapan, pengorganisasian, dan penugasan, serta kegiatan persiapan mobilisasi

12 Asep Dedi Suwasta, 2012, Tafsir Hukum Positif Indonesia, Alia Publishing, Bandung, hlm.9.

13 Jimly Asshiddiqie dan M. Ali Safa'at, 2006, Teori Hans Kelsen Tentang Hukum, Setjen dan Kepaniteraan MK RI, Jakarta, hlm.13. 
lainnya diselenggarakan oleh Panglima. Pengorganisasian menurut penjelasan ayat ini adalah penyusunan mobilisan dalam satuan perlawanan rakyat bersenjata dan satuan perlawanan rakyat tidak bersenjata. Dalam kaitan ini, maka Panglima TNI dalam keputusannya akan menentukan keberadaan suatu Satuan sebagai tempat bagi warga negara yang dimobilisasi untuk bernaung dibawahnya. Keadaan ini selanjutnya dapat ditafsirkan bahwa Komandan Satuan tempat dimana warga negara yang dimobilisasi bernaung merupakan Ankum dari warga negara yang dimobilisasi tersebut.

Bahwa adapun pengaturan kewenangan Ankum terhadap warga negara yang dimobilisasi meskipun dapat ditafsirkan secara sama dengan kewenangan Ankum terhadap Militer yang berada dibawah wewenang komandonya, namun hal ini dianggap masih terasa janggal, dan oleh sebab itu masih diperlukan pengaturan lanjutan yang bersifat lebih khusus dan terperinci sebagai gambaran yang utuh dari sebuah ciri-ciri produk hukum modern. Ciri-ciri hukum yang modern adalah adanya normanorma hukum yang tertulis, rasional, terencana, universal dan responsif dalam mengadaptasi perkembangan kemasyarakatan dan dapat menjamin kepastian hukum. ${ }^{14}$

I Gede Pantja Astawa dan Supri Na'a, 2008, Dinamika Hukum dan Ilmu Perundang-Undangan di Indonesia, Alumni, Bandung, hlm.1.
Menurut Gustav Radbruch seperti yang dikutip oleh Theo Huijbers menyatakan bahwa pengertian hukum dapat dibedakan tiga aspek yang ketigatiganya diperlukan untuk sampai pada pengertian hukum yang memadai. Aspek yang pertama ialah keadilan dalam arti yang sempit. Keadilan ini berarti kesamaan hak untuk semua orang di depan pengadilan. Aspek yang kedua ialah tujuan keadilan atau finalitas. Aspek ini menentukan isi hukum, sebab isi hukum memang sesuai dengan tujuan yang hendak dicapai. Aspek yang ketiga ialah kepastian hukum atau legalitas. Aspek itu menjamin bahwa hukum dapat berfungsi sebagai peraturan yang harus ditaati. ${ }^{15}$

Bahwa selain dimaksudkan sebagai upaya untuk menjamin kepastian hukum dari hal-hal yang bersifat kontradiktif dan kekaburan pada norma hukum, maka pengaturan secara lengkap terhadap warga negara yang dimobilisasidimaksudkansebagai upaya untuk menciptakan nilai-nilai ketertiban dan keadilan hukum, karena sesungguhnya warga sipil atau warga negara yang dimobilisasi memiliki kehidupan dan budaya tersendiri yang berbeda dengan kehidupan dan budaya pada organisasi Militer.

\footnotetext{
15 Theo Huijbers, 2007, Filsafat Hukum Dalam Lintas Sejarah, Kanisius, Yogyakarta, hlm. 163.
} 


\section{KESIMPULAN}

Berdasarkan uraian tentang kajian kewenangan Ankum terhadap warga negara yang dimobilisasi, dapat disimpulkan hal-hal sebagai berikut :

1. Bahwa UUHDM-2014 tidak memberikan pengaturan yang jelas dan tegas tentang kewenangan Ankum untuk menjatuhkan Hukuman Disiplin Militer terhadap warga negara yang dimobilisasi. Kewenangan Ankum yang disebutkan dalam UUHDM-2014 adalah kewenangan Ankum untuk menjatuhkan Hukuman Disiplin Militer secara terbatas kepada anggota Militer, dan tidak secara tegas mengatur kewenangan Ankum untuk menjatuhkan Hukuman Disiplin Militer terhadap warga negara yang dimobilisasi.

2. UUHDM-2014 juga tidak memberikan pengaturan yang jelas tentang perbedaan perlakuan terhadap warga yang dimobilisasi untuk melakukan perlawanan rakyat bersenjata dan perlawanan rakyat tidak bersenjata. UUHDM-2014 menganggap bahwa seluruh warga yang dimobilisasi tunduk kepada Hukum Disiplin Militer. Pemberlakuan ini bertentangan dengan UUMDD-1997 yang secara jelas dan tegas mengatur bahwa hanya terhadap warga yang dimobilisasi dalam suatu tugas untuk melakukan perlawanan rakyat bersenjata yang ditundukkan kepada Hukum Militer, sedangkan terhadap warga negara yang dimobilisasi untuk melakukan tugas perlawanan rakyat tidak bersenjata tidak tunduk pada Hukum Militer, dimana telah dipahami bahwa Hukum Disiplin Militer merupakan bagian dari Hukum Militer yang berlaku di Indonesia.

\section{DAFTAR PUSTAKA \\ BUKU}

Asshiddiqie, Jimly dan M. Ali Safa'at, 2006, Teori Hans Kelsen Tentang Hukum, Setjen dan Kepaniteraan MK RI, Jakarta.

Black, Henry Campbell, 1978, Black's Law Dictionary, West Publishing Co, USA.

Dedi Suwasta, Asep, 2012, Tafsir Hukum Positif Indonesia, Alia Publishing, Bandung.

Fajar ND, Mukti dan Yulianto Achmad, 2010, Dualisme Penelitian Hukum Normatif dan Hukum Empiris, Pustaka Pelajar, Yogyakarta.

HS, Salim dan ES Nurbani, 2014, Penerapan Teori Hukum Pada Penelitian Tesis Dan Desertasi, PT RajaGrafindo Persada, Jakarta.

Huijbers, Theo, 2007, Filsafat Hukum Dalam Lintas Sejarah, Kanisius, Yogyakarta. 
Mangesti, Yovita A. \& Bernard L. PERATURAN

Tanya, 2014, Moralitas Hukum, PERUNDANG-UNDANGAN

Genta Publishing, Yogyakarta. Undang-Undang Republik Indonesia

Mertokusumo, Sudikno, 2007, Nomor 27 Tahun 1997 tentang

Mengenal Hukum, Sebuah Mobilisasi dan Demobilisasi

Pengantar, Liberty, Yogyakarta. (Lembaran Negara Republik

M. Manullang, E. Fernando, 2007, Indonesia Tahun 1997 Nomor

Menggapai Hukum Berkeadilan

Tinjauan Hukum Kodrat dan

Antinomi Nilai, PT. Kompas

Media Nusantara, Jakarta.

75 Tambahan Lembaran Negara

Republik Indonesia Nomor 3704)

Undang-Undang Republik Indonesia

Nomor 31 Tahun 1997 tentang

Peradilan Militer. (Lembaran 2008, Dinamika Hukum dan Ilmu Perundang-Undangan di Indonesia, Alumni, Bandung.

Rifai, Ahmad, 2011, Penemuan Hukum Oleh Hakim Dalam Perspektif Hukum Progresif, Sinar Grafika, Jakarta.

\section{JURNAL}

Anshari, Natsri 2014, Perubahan Hukum Disiplin Militer : Disiplin Versus Keadilan, Jurnal Hukum Militer : Vol.2 No. 1., STHM, Jakarta.

Sudiro, 2014, Sanksi Hukum Disiplin Militer Dalam Penerapan Dan Konsep Rancangan UndangUndang Hukum Disiplin Militer, Jurnal Hukum Militer, Vol.2 No. 1., STHM, Jakarta.

Supriyatna, S, 2014, Pentingnya Hukum Disiplin Militer Ditinjau Dari Aspek Pembinaan Prajurit TNI, Jurnal Hukum Militer, Vol.2 No. 1., STHM, Jakarta.

Negara Republik Indonesia

Tahun 1997 Nomor 84 Tambahan Lembaran Negara Republik Indonesia Nomor 3713)

Undang-Undang Republik Indonesia Nomor 25 Tahun 2014 tentang Hukum Disiplin Militer. (Lembaran Negara Republik Indonesia Tahun 2014 Nomor 257 Tambahan Lembaran Negara Republik Indonesia Nomor 5591). 